\title{
TP53 and PIK3CA gene mutations in adenocarcinoma, squamous cell carcinoma and high-grade intraepithelial neoplasia of the cervix
}

\author{
Maria Lina Tornesello ${ }^{*}$, Clorinda Annunziata', Luigi Buonaguro', Simona Losito², Stefano Greggi ${ }^{3}$ \\ and Franco M Buonaguro'
}

\begin{abstract}
Background: Mutations in the tumor suppressor gene TP53 and proto-oncogene PIK3CA and alterations of p53 and PIK3CA AKT mTOR pathways are common events in several human cancers. We focused on the analysis of TP53 and PIK3CA gene variations in adenocarcinoma, squamous cell carcinoma as well as in intraepithelial neoplasia grade 3 of the cervix.

Methods: DNA samples from 28 cervical adenocarcinoma, 55 squamous cell carcinoma and 31 intraepithelial neoplasia grade 3 (CIN3), previously characterized in terms of human papillomavirus (HPV) prevalence and genotype distribution, were analyzed for TP53 and PIK3CA mutations in the exons 4-9 and exon 9, respectively.

Results: Single nucleotide substitutions in TP53 and PIK3CA genes were detected in 36\% and 11\% of adenocarcinoma, in 16\% and in 5\% of squamous cell carcinoma, and in 13\% and none of CIN 3, respectively. Nucleotide changes in TP53 were significantly more frequent in adenocarcinoma cases than in squamous cell carcinoma and CIN3 $(P=0.035)$ and were independent from HPV infection status.

Conclusions: Mutations in the TP53 gene and to lesser extent in the PIK3CA gene seem more frequent in cervical adenocarcinoma than in squamous cell carcinoma and CIN3. Whether TP53 and PIK3CA gene mutations have an impact on prognosis and response to molecularly targeted therapies as well as in cytotoxic drugs in different cervical cancer histotypes needs to be analyzed in investigative clinical trials.
\end{abstract}

Keywords: TP53 gene, PIK3CA gene, Cervix, Squamous cell carcinoma, Adenocarcinoma, Cervical intraepithelial neoplasia

\section{Introduction}

Cervical cancer is the fourth most common cancer diagnosed in women worldwide with an estimated 527,624 new cases and 265,653 deaths in 2012 [1]. The major histopathologic types are squamous cell carcinoma and adenocarcinoma which constitute about $85 \%$ and $10-12 \%$ of all cases of cervical cancer, respectively. The squamous cell carcinoma arises in the squamocolumnar junction between the ectocervical squamous epithelium and the endocervical columnar epithelium and is preceded by a long phase of

\footnotetext{
* Correspondence: m.tornesello@istitutotumori.na.it

"Molecular Biology and Viral Oncology Unit, Istituto Nazionale Tumori "Fond Pascale" - IRCCS - Via Mariano Semmola, 80131 Napoli, Italy

Full list of author information is available at the end of the article
}

cervical intraepithelial neoplasia (CIN1, CIN2 and CIN3) [2]. The adenocarcinoma originates from glandular precursor lesions of the endocervical mucosa and comprises several histological subtypes such as the mucinous adenocarcinoma (intestinal, endocervical or signet-ring), the endometrioid and non-mucinous adenocarcinoma (clear cell, serous) [3].

Oncogenic HPVs, mainly HPV 16 and 18 genotypes, have been strongly associated with the risk to develop intraepithelial lesions, squamous cell carcinoma and adenocarcinoma of the cervix [4]. However, the majority of HPV infections induce low grade squamous epithelial lesions that in more than $90 \%$ of cases spontaneously regress and in about $10 \%$ become transforming infections, characterized by several molecular changes [5]. The early 
genes E6 and E7 of high risk HPVs are consistently expressed in HPV-related cancers and derived tumor cell lines and contribute to the transformation of infected epithelial cells mainly through the inactivation of p53 and $\mathrm{pRb}$ oncosuppressors and related pathways [6]. However, the constitutive expression of early viral genes is not in itself sufficient to induce and maintain the transformation status and accumulation of genetic and/ or epigenetic alterations over time may be crucial for the ultimate progression to cancer $[5,7,8]$.

A number of studies have demonstrated that adenocarcinoma has worse prognosis with higher rates of metastases and decreased survival compared with squamous cell carcinoma [9]. However, few studies have examined whether distinct molecular profiles underlie the pathogenesis of the two types of cervical cancer.

Several cellular genes such as TP53 [10,11], PIK3CA [12], c-Myc (Myc) and ErbB2 [13], cIAP1 [14], Ras [15], PTEN [16] and LKB1 [17] have been found mutated or functional inactivated in variable proportions of cervical cancers. Comprehensive analysis of genomic aberrations in cervical tumors allowed to identify, besides the previously characterized mutations in TP53 and PIK3CA genes, unknown mutations in MAPK1, HLA-B, EP300, FBXW7, NFE2L2, and ERBB2 genes in squamous cell carcinoma and somatic mutations of ELF3 (13\%) and CBFB (8\%) genes in adenocarcinomas [18].

Mutations in TP53 gene are among the most common genetic alterations in many human malignancies [19-23]. Up to $90 \%$ of TP53 mutations are non-synonymous and determine single amino-acid changes primarily within the DNA binding domain region (exon 5-8) located between codons 125 and 300 [24]. In a recent meta-analysis, including 1353 cervical tumors the frequency of nonsynonymous mutations in the DNA-binding domain of the TP53 gene was found significantly higher in adenocarcinoma (32 of $241 ; 13.3 \%$ ) compared to squamous cell carcinoma (39 of 657; 5.9\%; $\mathrm{P}=0.0003, \mathrm{X}^{2}$ test), [10]. The proportion of adenocarcinoma with mutated TP53 varied from 4\% in North America to 19\% in Asia. Among the six hot-spot codons of TP53 gene only three codons (175, 248 and 273) were found commonly mutated in both types of cervical cancer. No study, however, has systematically analyzed the frequency of TP53 mutations in different histological types of adenocarcinoma, in squamous cell carcinoma and in pre-invasive neoplastic lesions of the cervix [10].

A number of studies reported that the phosphoinositide-3-kinase-catalytic-alpha (PIK3CA) gene is frequently mutated in the helical domain within exon 9 (codons 542 and 545) and in the kinase domain within exon 20 (codon 1047) of several types of human cancer [25]. In cervical cancer activating mutations in PIK3CA gene have been found almost exclusively in exon 9 [18,26-28]. Knowledge of mutational status of PIK3CA gene is particularly relevant considering that several anticancer drugs, targeting PI3K/Akt pathway, have given promising preliminary results in human malignancies [29]. McIntyre et al. (2013) have recently reported that in cervical cancer patients treated with radical chemoradiotherapy the PIK3CA mutation status was strongly associated with overall survival in FIGO stage IB/II but not stage III/IVA [26]. In addition, PIK3CA mutations in patients with advanced breast, ovarian, endometrial, and cervical cancers have been found associated with a higher response rate to treatments that include PI3K/AKT/mTOR inhibitors [30]. These observations suggest that PIK3CA could represent a potential drug targetable molecule for the treatment of cervical cancer.

We performed a retrospective study investigating the frequency of TP53 and PIK3CA mutations in pretreatment biopsies from a cohort of patients with mucinous and non-mucinous adenocarcinoma, squamous cell carcinoma and CIN 3 and we correlated the TP53 and PIK3CA mutational status with histological subtypes and HPV status.

\section{Materials and methods}

\section{Patient and tissue samples}

One hundred and fourteen formalin-fixed and paraffinembedded cervical neoplasia biopsies from patients referred to the Gynecology Unit at the National Cancer Institute Fond Pascale, from 2002 to 2008, were included in the study. All cases have been previously characterized in terms of histology, DNA quality and HPV genotypes [31,32]. In particular, from each paraffin block, an initial $10-\mu \mathrm{m}$ thick section was obtained for hematoxylin-eosin staining, followed by four $10 \mu \mathrm{m}$ sections that were collected in separate sterile Eppendorf tubes for PCR analysis. Slides immediately adjacent to the tissue section used for gene mutation analysis were reviewed by the pathologist to verify the presence of neoplastic tissue. This morphological check showed that the mean percentage of tumour cells staining was $64 \%$ (range 10-100\%). Histological subtypes were determined in accordance to Young et al. [33] and to The Bethesda 2001 system. Tissues were graded as mucinous adenocarcinoma (endocervical and intestinal types, $\mathrm{n}=12$ ), non-mucinous adenocarcinoma (endometrioid, clear cell and serous types, $n=14$ ), mixed adenocarcinoma $(n=2)$, invasive squamous cell carcinoma $(n=55)$ and CIN 3, according to the highest grade present within a lesion.

Genomic DNA was extracted according to published procedures [34]. In particular tissue samples were deparaffinized in xylenes and digested with Proteinase K (150 $\mu \mathrm{g}$ per $\mathrm{ml}$ at $60^{\circ} \mathrm{C}$ for $30 \mathrm{~min}$ ) in $100 \mu \mathrm{l}$ of lysis buffer (10 mM Tris- $\mathrm{HCl} \mathrm{pH}$ 7.6, $5 \mathrm{mM}$ EDTA, $150 \mathrm{mM} \mathrm{NaCl}$, $1 \%$ SDS), followed by DNA purification by phenol and 
phenol-chloroform-isoamyl alcohol (25:24:1) extraction and ethanol precipitation in $0.3 \mathrm{M}$ sodium acetate $(\mathrm{pH}$ 4.6). The study was approved by the institutional review board of the Istituto Nazionale Tumori Pascale.

\section{TP53 codon 4-9 mutational analysis}

The analysis of TP53 gene in exons 4-9 was performed using specific oligonucleotides and amplification protocols according to the IARC guidelines (http://www-p53.iarc.fr/ Download/TP53_DirectSequencing_IARC.pdf). All PCR reactions were undertaken using 10 to $100 \mathrm{ng}$ genomic DNA in $50-\mu \mathrm{L}$ reaction mixture following the IARC amplification procedures using in all reactions the Hot Master buffer and the Hot Master Taq DNA Polymerase (5 Prime GmbH, Hamburg, Germany). DNAs were amplified in a Perkin-Elmer GeneAmp PCR System 9700 thermal cycler. All samples with sufficient amount of DNA were subjected to bidirectional direct sequencing analysis by Primm Srl Laboratories (Milan, Italy).

\section{PIK3CA codon 9 mutational analysis}

PIK3CA codon 9 was amplified by a seminested PCR using in the outer reaction the oligoprimer PIK3-9-F1 (5' - TGGTCTTGTT GTTGGCTAA) with PIK3-9-R1 (5' - CTTACCTGTGACTCCATAGAA), generating a 410 $\mathrm{bp}$, and in the inner reaction the oligoprimer PIK3-9-F2 (5' - ACTATTCTGTGACTGGTGTAAT) with PIK3-9-R1, generating a $381 \mathrm{bp}$ fragment encompassing the hot spot codons 542 and 545 and designed to avoid amplification of the PIK3CA pseudogene. PCR reactions were performed in $50 \mu \mathrm{L}$ reaction mixture containing 50 to $100 \mathrm{ng}$ of target DNA, 5 pmol of each primer, $2.5 \mathrm{mM} \mathrm{MgCl} 2$,
$50 \mathrm{mM}$ of each dNTP and $5 \mathrm{ul}$ Hot Master buffer and $1 \mathrm{U}$ of Hot Master Taq DNA Polymerase (5 Prime $\mathrm{GmbH}$, Hamburg, Germany). DNA was amplified in a PerkinElmer GeneAmp PCR System 9700 thermal cycler with the following steps: an initial 1-min denaturation at $94^{\circ} \mathrm{C}$, followed by 45 amplification cycles of $58^{\circ} \mathrm{C}$ for $30 \mathrm{sec}$, $72^{\circ} \mathrm{C}$ for $30 \mathrm{sec}, 94^{\circ} \mathrm{C}$ for $30 \mathrm{sec}$ and a 1 -min final annealing at $58^{\circ} \mathrm{C}$ followed by 5 -min elongation at $72^{\circ} \mathrm{C}$. All samples were subjected to bidirectional direct sequencing analysis.

\section{Statistical analyses}

The planned test for statistical evaluation were Fisher's exact test, Yates corrected $\chi^{2}$ test or $\chi^{2}$ test for trend, as appropriate, to compare the proportions of cases mutated in TP53 or PIK3CA genes among patients stratified by, age, tumour hystotype and HPV infection. All analyses were performed with Epi Info 6 Statistical Analysis System Software (6.04d, 2001, Centers for Disease Control and Prevention, USA). Differences were considered to be statistically significant when $P$ values were less than 0.05 .

\section{Results}

A total of 114 patients with cervical adenocarcinoma, squamous cell carcinoma and CIN 3 were analyzed for the presence of mutations in exons 4-9 of TP53 and exon 9 of PIK3CA genes (Table 1). Twenty-eight patients (25\%) were diagnosed with adenocarcinoma carcinoma, 55 (48\%) with squamous cell carcinoma and 31 (27\%) with CIN 3. The prevalence of high risk HPV was $72 \%$ in adenocarcinoma, $85 \%$ in squamous cell carcinoma and

Table 1 TP53 and PIK3CA mutations and tumor clinical characteristics $(n=114)$

\begin{tabular}{|c|c|c|c|c|c|c|c|c|c|c|}
\hline \multirow[b]{2}{*}{ Variable } & \multicolumn{2}{|c|}{$\begin{array}{l}\text { TP53 mutant } \\
(\mathrm{n}=23)\end{array}$} & \multicolumn{2}{|c|}{$\begin{array}{l}\text { TP53 wild type } \\
(\mathrm{n}=91)\end{array}$} & \multirow[t]{2}{*}{$P$ value } & \multicolumn{2}{|c|}{$\begin{array}{l}\text { PI3KCA mutant } \\
(n=6)\end{array}$} & \multicolumn{2}{|c|}{$\begin{array}{l}\text { PIK3CA wild type } \\
(\mathrm{n}=108)\end{array}$} & \multirow[t]{2}{*}{$P$ value } \\
\hline & $\mathrm{n}$ & $(\%)$ & $n$ & $(\%)$ & & & & & & \\
\hline Mean age [SD] & 48.7 & {$[ \pm 10.6]$} & 51.4 & {$[ \pm 14.7]$} & 0.326 & 56.9 & {$[ \pm 10.5]$} & 50.9 & {$[ \pm 14.5]$} & 0.364 \\
\hline Histology & & & & & $0.035^{*}$ & & & & & $0.400^{* *}$ \\
\hline Adenocarcinoma $(n=28)$ & 10 & (36) & 18 & $(64)$ & & 3 & $(11)$ & 25 & $(89)$ & \\
\hline Squamous carcinoma $(n=55)$ & 9 & (16) & 46 & (84) & & 3 & (5) & 52 & $(95)$ & \\
\hline CIN $3(n=31)$ & 4 & (13) & 27 & $(87)$ & & 0 & & & & \\
\hline Grading*** & & & & & 0.603 & & & & & 0.664 \\
\hline $\mathrm{G} 1(n=5)$ & 0 & & & & & 0 & & & & \\
\hline$G 2(n=23)$ & 7 & $(30)$ & 16 & $(70)$ & & 1 & (4) & 22 & (96) & \\
\hline $\mathrm{G} 3(\mathrm{n}=55)$ & 12 & $(22)$ & 43 & (78) & & 5 & (9) & 50 & $(91)$ & \\
\hline \multicolumn{11}{|l|}{ HPV status } \\
\hline Negative $(n=37)$ & 10 & $(27)$ & 27 & (73) & & 4 & $(11)$ & 33 & (89) & \\
\hline Positive $(n=77)$ & 13 & (17) & 64 & (83) & & 2 & (3) & 75 & $(97)$ & \\
\hline
\end{tabular}

${ }^{*} x^{2}$ for trend $=4.44$.

**Fisher exact test.

***Well differentiated (G1); Moderately differentiated (G2); Poorly differentiated carcinoma (G3). 
55\% in CIN 3 cases. HPV16 was the most frequent viral genotype in all histological categories being present in $67 \%, 81 \%$ and $74 \%$ of HPV-related adenocarcinoma, squamous cell carcinoma and CIN 3, respectively [31,32].

TP53 gene was mutated in 10 out of 28 (36\%) adenocarcinoma, in 9 out of 55 (16\%) squamous cell carcinoma and in 4 out of 31 (13\%) of CIN 3 cases. In particular 46\%, 7.9\% and 15.3\% of HPV16-positive adenocarcinoma, squamous cell carcinoma and CIN3, respectively, harbored mutations in TP53 gene. One out of nine $(11.1 \%)$ squamous cell carcinoma positive for high risk HPVs other than type 16 was mutated in TP53 gene. None of adenocarcinoma and CIN3 cases positive for high risk HPVs other than type 16 were mutated in the exons 4-9 of TP53 gene. Among HPV-negative samples 50\%, 75\% and $7.1 \%$ of adenocarcinoma, squamous cell carcinoma and
CIN3, respectively, were mutated in the TP53. The most common nucleotide changes were missense mutations $(\mathrm{n}=17)$ affecting the DNA binding domain of $\mathrm{p} 53$ (Table 2). Interestingly, in 5 cases the single nucleotide substitution appeared as an homozygous mutation suggesting that major genetic alterations including loss of heterozygosity affected chromosome 17 (Figure 1). No insertion or deletions were detected. TP53 mutations were significantly more frequent in adenocarcinoma $\left(\chi^{2}\right.$ for trend $=4.44, P=0.035$ ), mainly in the mucinous endocervical adenocarcinoma histotype (54\%), compared to squamous cell carcinoma and CIN3 (Table 3). The combined mutational pattern of TP53 and PIK3CA genes showed that a relevant proportion of nucleotide changes was represented by C:G > T:A transitions (39\%) potentially arising from deamination of DNA bases.

Table 2 Histological characteristics of cervical samples, HPV status, TP53 (exons 4-9) and PIK3CA (exon 9) mutations

\begin{tabular}{|c|c|c|c|c|c|c|}
\hline Patient no & Histology & HPV & TP53 Mut & & PIK3CA Mut & \\
\hline AC206 & Mucinous Endocervical Adenocarcinoma & HPV16E & $\mathrm{T} 231 \mathrm{~N}$ & $C>A$ & & \\
\hline AC134 & Mucinous Endocervical Adenocarcinoma & HPV16 E,18 & M237K & $T>A$ & & \\
\hline \multirow[t]{2}{*}{ AC174 } & \multirow[t]{2}{*}{ Mucinous Endocervical Adenocarcinoma } & \multirow[t]{2}{*}{ Neg } & $\mathrm{C} 258 \mathrm{C}$ & $A>T$ & & \\
\hline & & & G295N & $A>T$ & & \\
\hline AC213 & Mucinous Endocervical Adenocarcinoma & HPV16 AA & S095F & $C>T$ & & \\
\hline AC214 & Mucinous Endocervical Adenocarcinoma & HPV16 E & SO90S & $C>T$ & & \\
\hline AC198 & Mucinous Endocervical Adenocarcinoma & Neg & P092L & $C>T$ & E547K & $G>A$ \\
\hline AC193 & Mucinous Endocervical Adenocarcinoma & Neg & A307S & $G>T$ & S541Y & $C>A$ \\
\hline AC201 & Mucinous Endometrioid Adenocarcinoma & HPV16 E & E286E & $A>G$ & & \\
\hline AC218 & Mucinous Endometrioid Adenocarcinoma & HPV16 E & & & Q546Q & $G>A$ \\
\hline AC199 & Non-mucinous Serous Adenocarcinoma & Neg & M237I & $G>C$ & & \\
\hline AC210 & Non-mucinous Serous Adenocarcinoma & HPV16 & Y236C & $A>G$ & & \\
\hline SCC005 & Squamous Cell Carcinoma & Neg & Y163C & $A>G$ & & \\
\hline SCC008 & Squamous Cell Carcinoma & Neg & $\mathrm{H} 296 \mathrm{H}$ & $C>T$ & & \\
\hline SCC010 & Squamous Cell Carcinoma & Neg & $|162|$ & $C>T$ & & \\
\hline SCC107 & Squamous Cell Carcinoma & HPV16 & int 14077 & $C>T$ & & \\
\hline SCC022 & Squamous Cell Carcinoma & HPV16 & P250T & $C>A$ & & \\
\hline SCC032 & Squamous Cell Carcinoma & HPV16 & 12551 & $C>T$ & & \\
\hline sCC036 & Squamous Cell Carcinoma & HPV45 & G245D & $G>A$ & & \\
\hline SCC045 & Squamous Cell Carcinoma & Neg & S260T & $T>A$ & & \\
\hline SCC052 & Squamous Cell Carcinoma & Neg & Y236T & $C>T$ & & \\
\hline SCC034 & Squamous Cell Carcinoma & Neg & & & $\mathrm{E} 545 \mathrm{~A}$ & $A>C$ \\
\hline SCC006 & Squamous Cell Carcinoma & HPV16 & & & E545K & $G>A$ \\
\hline SCC019 & Squamous Cell Carcinoma & Neg & & & D527N & $G>A$ \\
\hline SCC064 & Squamous Cell Carcinoma & Neg & $\mathrm{C} 242 \mathrm{C}$ & $C>T$ & & \\
\hline CIN085 & Cervical Intraepithelial Neoplasia 3 & HPV16 & V143A & $\mathrm{T}>\mathrm{C}$ & & \\
\hline \multirow[t]{2}{*}{ CIN090 } & \multirow[t]{2}{*}{ Cervical Intraepithelial Neoplasia 3} & \multirow[t]{2}{*}{ Neg } & Y95Y & $C>T$ & & \\
\hline & & & $\mathrm{R} 282 \mathrm{~W}$ & $C>T$ & & \\
\hline CIN099 & Cervical Intraepithelial Neoplasia 3 & HPV16 & int 13305 & $C>T$ & & \\
\hline
\end{tabular}




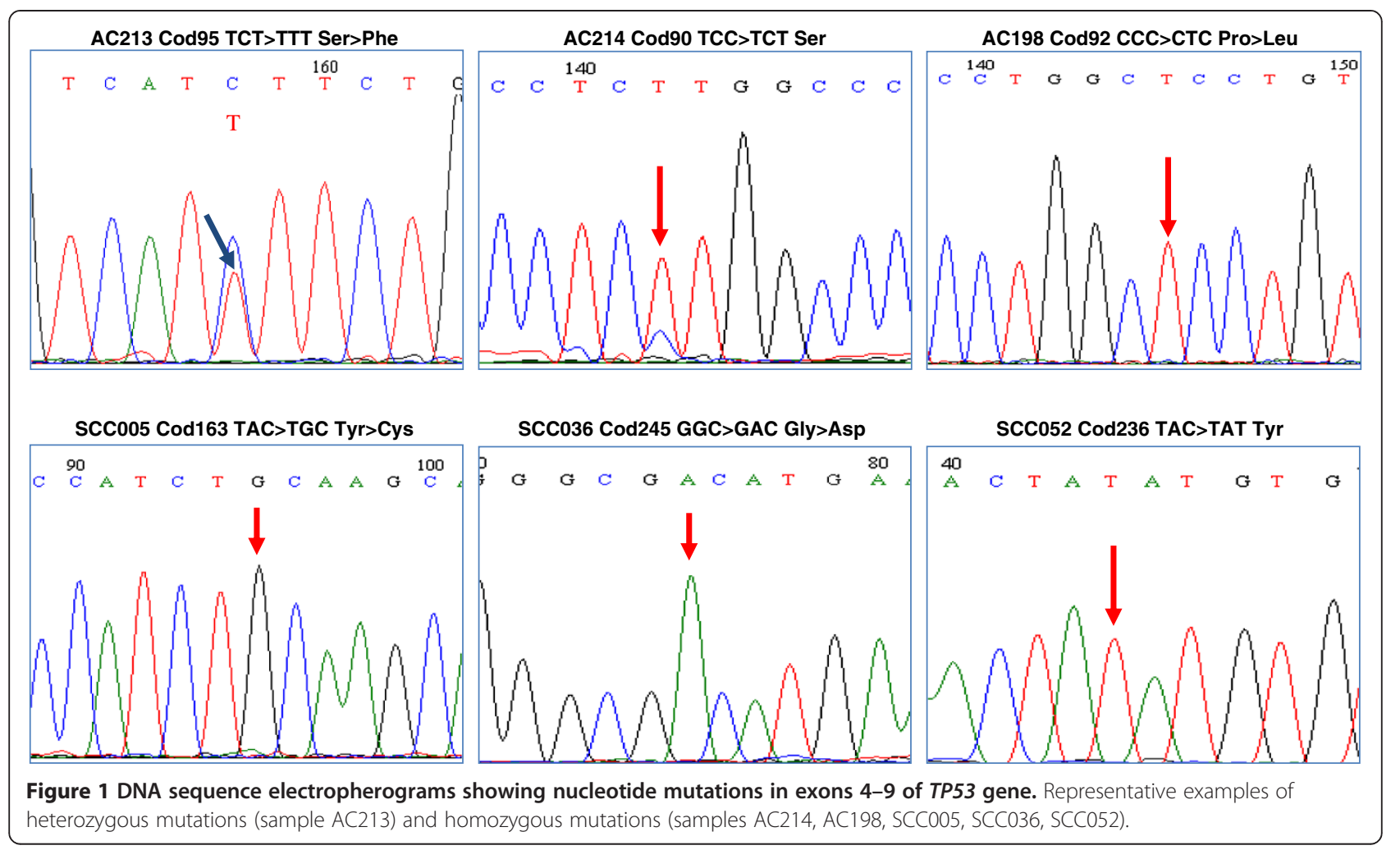

There was no statistically significant difference in TP53 gene mutation frequency between HPV-positive and HPV-negative samples in all histological groups.

The exon 9 of PIK3CA gene was found mutated in six (5\%) out of 114 cases (Table 1). Non-synonymous mutations were identified in three (11\%) of the adenocarcinomas at codons 541 (TCT $>$ TAT, Ser $>$ Tyr), 546 (CAG > CAA, Gln $>$ Gln) and 547 (GAG > AAG, Glu > Lys), and in all three cases the sequence electropherograms showed homozygous mutations suggestive of major chromosomal

Table 3 Frequency of TP53 and PIK3CA mutations in cervical adenocarcinoma according to histological subtypes

\begin{tabular}{lllll}
\hline & \multicolumn{3}{l}{ TP53 Mut } & \multicolumn{2}{l}{ PIK3CA Mut } \\
\hline Diagnosis & $\mathbf{n}$ & (\%) & $\mathbf{n}$ & (\%) \\
Mucinous adenocarcinoma & & & & \\
$\quad$ Endocervical $(\mathrm{n}=11)$ & 6 & $(54)$ & 2 & $(18)$ \\
$\quad$ Intestinal $(\mathrm{n}=1)$ & 0 & & 0 & \\
Endometrioid $(\mathrm{n}=8)$ & 2 & $(25)$ & 1 & $(12)$ \\
Non-mucinous adenocarcinoma & & & & \\
$\quad$ Clear cell $(\mathrm{n}=2)$ & 0 & & 0 & \\
$\quad$ Serous $(\mathrm{n}=4)$ & 2 & $(40)$ & 0 & \\
Mixed adenocarcinoma $(\mathrm{n}=2)^{*}$ & 0 & & 0 & \\
All adenocarcinoma $(\mathrm{n}=28)$ & 10 & $(36)$ & 3 & $(11)$ \\
\hline
\end{tabular}

*Serous/Glassy cells Adenocarcinoma $(n=1)$; Intestinal/signet ring cell Adenocarcinoma $(n=1)$. aberrations affecting the 3q26.3 loci (Figure 2). Heterozygous mutations in PIK3CA gene were found in three cases (5\%) of squamous cell carcinoma at codons 527 (GAC > AAC, Asp > Asn) and 545 (GAG > AAG, Glu > Lys; GAG > GCG, Glu > Ala). Two of the three PIK3CA mutated samples were HPV negative. No mutation in PIK3CA gene was detected in DNA samples extracted from CIN3 samples.

\section{Discussion}

Persistent infection with high risk HPVs, the increased expression of E6 and E7 oncoproteins and HPV integration into human DNA, along with chromosomal aberrations and gene alteration at the integration sites, are considered significant features of progression from pre-invasive to invasive cervical cancer $[5,35,36]$. Few studies, however, have systematically analyzed genetic alterations in HPV-related genital cancers and their significance for cancer staging and as predictive biomarkers.

In this study we observed that $20 \%$ of cervical neoplasia cases were mutated in TP53 gene. The prevalence was highest in adenocarcinoma (36\%), followed by squamous cell cervical cancer (16\%) and CIN3 (13\%). Although the small number of cases analyzed in this study precludes definitive conclusions regarding the absolute difference in mutation rates among the different histological types of cervical cancer groups, the results are in agreement with data obtained from COSMIC databes [10]. However, 


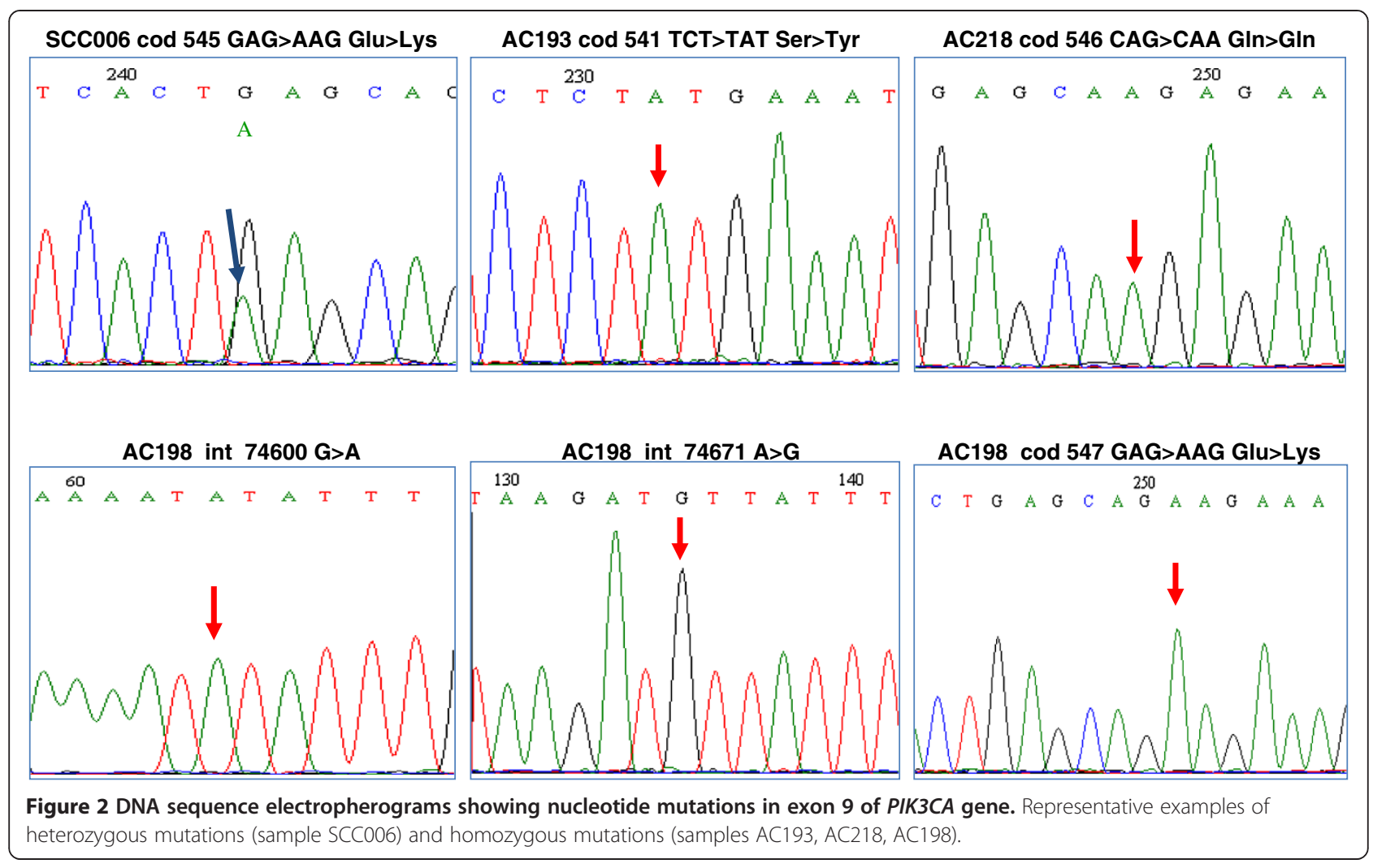

Ojesina et al. reported similar mutation frequencies (5\%) of TP53 gene and different mutation profiles of other genes in adenocarcinoma and squamous cell carcinoma. Specifically, in squamous cell carcinomas mutations included recurrent E322K substitutions in the MAPK1 gene (8\%), inactivating mutations in the HLA-B gene (9\%), and mutations in EP300 (16\%), FBXW7 (15\%), NFE2L2 (4\%), TP53 (5\%) and ERBB2 (6\%). In adenocarcinoma variations included somatic mutations in ELF3 (13\%) and CBFB (8\%) genes [18]. On the other hand, the identification of KRAS mutations in $17 \%$ of adenocarcinoma and in none of squamous carcinoma samples strongly suggests that they have distinct molecular profiles [28].

The pattern of TP53 mutations was similar in cervical adenocarcinoma and squamous cell carcinoma and showed an excess of C:G to T:A transitions. This type of mutations, which are the most common in all human cancers, may originate from spontaneous nucleotide changes deriving from deamination of methyl-cytosine [4]. However, it is unclear whether their relative high frequency in cervical cancer may be related to a specific carcinogen or to the excess of oxygen and nitrogen radicals produced by oxidant-generating enzymes during chronic inflammation [37-41]. We found an excess of TP53 mutations in the mucinous endocervical histotype (54\%), however no other study to date addressed the issue of gene mutation distribution across the different subtypes of adenocarcinoma such as endocervical, endometrioid, intestinal, and mixed adenocarcinoma.

Very few studies have analyzed the possible association between mutations in TP53 gene and prognosis or treatment outcome in adenocarcinoma and squamous cell carcinoma of the cervix. One study has explored whether p53 status, HPV, and LOH on chromosome 3p21.3, 6p21.2, 17p13.1 (on which TP53 gene is located), and $18 \mathrm{q} 21.2$ are associated with prognosis and treatment outcome in 60 patients with squamous cell carcinoma and 5 with adenocarcinoma of the cervix after radiotherapy. Statistical significant differences were observed between tumor size and clinical stage $(\mathrm{P}=0.0006)$, p53 status $(\mathrm{P}=0.045)$, and $\mathrm{LOH}$ on $17 \mathrm{p} 13.1(\mathrm{P}=0.02)$ [42]. No significant differences in the overall survival and disease-free survival between patients with wild-type p53 and those with mutant p53 were observed in their study. Although, the statistical analysis was hampered by the small number of cases with mutant TP53 (10.8\% of carcinomas).

We analyzed exon 9 of PIK3CA gene, encoding for the highly conserved helical domain of the p110alpha catalytic subunit of PI3K, and identified mutations in $11 \%$ of adenocarcinoma and $5 \%$ of squamous cell cervical cancer (5\%) and no mutations in the pre-invasive lesions. These results are in agreement with PIK3CA mutation frequencies reported in COSMIC (Catalogue of Somatic Mutations in Cancer) database (11\% and $14 \%$ in adenocarcinoma and 
squamous cell carcinoma, respectively) and with those recently obtained by whole exome sequencing analysis of cervical cancer genomes (PIK3CA mutation frequencies of $12.5 \%$ and $12.6 \%$ in adenocarcinoma and squamous cell carcinoma, respectively) [18,43]. Moreover, Cui et al. [44] analyzing exon 1, 9 and 20 of PIK3CA gene in cervical carcinomas and CIN3 lesions identified somatic mutations in $8.15 \%$ of cervical carcinomas but no mutations in CIN3 cases suggesting that genetic alterations of this protooncogene are late events during carcinogenesis. Much higher frequencies of PIK3CA mutations, however, were found both in adenocarcinoma (37.5\%) and in cervical squamous carcinoma (25\%) by mass-spectrometry based analyses $[28,45]$, suggesting either that this technique is much more sensitive than Sanger sequencing or that cancer cases from different populations have different rates of PIK3CA mutations.

Interestingly in our study PIK3CA gene showed homozygous nucleotide substitutions in all mutated adenocarcinoma suggesting that major genetic alterations affected the locus 3q26.3, where the PIK3CA gene is located. Indeed, a recent meta-analysis showed that the most frequent chromosomal aberrations in cervical carcinoma (SCC) occurred as gains $(0.55,95 \%$ CI $0.43-0.70)$ or losses at $3 p(0.36,95 \%$ CI $0.27-0.48)$, specifically at the $3 q 25-3 q 29$ loci [46]. Genomic gains of locus 3q26 have been associated with the progression from high-grade cervical disease to cancer being detected at lower rate in earlier stages of cervical carcinogenesis and shown to increase with the severity of cervical lesions [47-51]. No study has yet investigated the correlation between the mutation frequency of PIK3CA gene and $3 \mathrm{q}$ chromosomal aberration frequency.

Mutated PIK3CA gene is becoming a promising target for newly discovered anticancer drugs. Janku et al. reported that among patients affected by advanced breast, cervical, endometrial, and ovarian cancers, those with PIK3CA mutations treated with $\mathrm{PI} 3 \mathrm{~K} / \mathrm{AKT} / \mathrm{mTOR}$ inhibitors demonstrated a higher response rate than patients without mutations [30]. In particular among the 23 PIK3CA-mutant patients with breast and gynecologic cancers who experienced treatment failure with standard therapies, was observed a response rate of $30 \%$, which is significantly favorable compared to a $10 \%$ response rate in cancer patients with wild type PIK3CA treated on the same protocols $(\mathrm{P}=0.04)$ [30]. Moreover, McIntyre et al. reported an association between tumoral PIK3CA mutational status and overall survival in patients with cervical cancer treated with radical chemo-radiotherapy. In particular the PIK3CA mutation status was strongly associated with overall survival in FIGO stage IB/II patients, unadjusted hazard ratio 6.0 (95\% CI 2.1-17.5), $\mathrm{p}=0.0002$, but not stage III/IVA patients, unadjusted hazard ratio 1.0 (95\% CI 0.32-3.1), $\mathrm{p}=0.98$ [26]. Further prospective clinical trials evaluating patients with $P I K 3 C A$ positive tumors are required to evaluate response to targeted agents such as PI3K inhibitors.

The main limitations of our study include the small sample size and the retrospective design that do not allow the appropriate evaluation of the clinical significance of TP53 and PIK3CA mutants in terms of overall survival, metastasis-free survival and outcome to therapies. Prospective longitudinal studies are needed to define if the knowledge of TP53 and/or PIK3CA status could provide relevant information for the management of individual patients with different histotypes of adenocarcinoma and squamous cell carcinoma of the cervix.

\section{Conclusions}

In conclusion, our results show distinct mutation profiles in TP53 and PIK3CA genes in cervical adenocarcinoma, squamous cell carcinoma and CIN3. Knowledge of genetic alterations in different cervical cancer histotypes, in addition to currently used viral testing, may provide a basis for future research directions in early diagnostics and personalization of therapy.

\section{Competing interests}

The authors declare that they have no competing interests.

\section{Authors' contributions}

$M L T$ designed the study and wrote the paper; CA conducted the sample analysis; LB contributed to the statistical analyses; SL and GB performed histopathological evaluation; SG provided the clinical samples; FMB supervised the whole project. All authors read and approved the final manuscript.

\section{Acknowledgements}

This work was supported by grants from Ministero della Salute (Programma Integrato Oncologia RO4/2007 and Ricerca Corrente 2011) and from ICSC-World Laboratory (project MCD-2/7). We are grateful to the patients for their participation in this study. We are also grateful to Immacolata De Biase and Lucrezia Femiano for their technical support.

\section{Author details}

'Molecular Biology and Viral Oncology Unit, Istituto Nazionale Tumori "Fond Pascale" - IRCCS - Via Mariano Semmola, 80131 Napoli, Italy. ${ }^{2}$ Pathology Department, Istituto Nazionale Tumori "Fond Pascale" - IRCCS - Via Mariano Semmola, 80131 Napoli, Italy. ${ }^{3}$ Uro-gynecology Department, Istituto Nazionale Tumori "Fond Pascale" - IRCCS - Via Mariano Semmola, 80131 Napoli, Italy.

Received: 27 June 2014 Accepted: 4 September 2014

Published online: 16 September 2014

\section{References}

1. Ferlay J, Soerjomataram I, Ervik M, Dikshit R, Eser S, Mathers C, Rebelo M, Parkin DM, Forman D, Bray F: GLOBOCAN 2012 v1.0, Cancer Incidence and Mortality Worldwide: IARC CancerBase No. 11. Lyon, France: International Agency for Research on Cancer; 2013. http://globocan.iarc.fr. 2013. Ref Type: Electronic Citation.

2. Spriggs Al, Boddington MM: Progression and regression of cervical lesions. Review of smears from women followed without initial biopsy or treatment. J Clin Pathol 1980, 33:517-522.

3. Christopherson WM, Nealon N, Gray LA Sr: Noninvasive precursor lesions of adenocarcinoma and mixed adenosquamous carcinoma of the cervix uteri. Cancer 1979, 44:975-983.

4. Bouvard V, Baan R, Straif K, Grosse Y, Secretan B, El GF, El Ghissassi F, Benbrahim-Tallaa L, Guha N, Freeman C, Galichet L, Cogliano V, WHO 
International Agency for Research on Cancer Monograph Working Group: A review of human carcinogens-Part B: biological agents. Lancet Oncol 2009, 10:321-322.

5. Steenbergen RD, Snijders PJ, Heideman DA, Meijer CJ: Clinical implications of (epi)genetic changes in HPV-induced cervical precancerous lesions. Nat Rev Cancer 2014, 14:395-405.

6. Moody CA, Laimins LA: Human papillomavirus oncoproteins: pathways to transformation. Nat Rev Cancer 2010, 10:550-560.

7. Zur Hausen $\mathrm{H}$ : Papillomaviruses and cancer: from basic studies to clinical application. Nat Rev Cancer 2002, 2:342-350

8. Hafner N, Driesch C, Gajda M, Jansen L, Kirchmayr R, Runnebaum IB, Dürst M: Integration of the HPV16 genome does not invariably result in high levels of viral oncogene transcripts. Oncogene 2008, 27:1610-1617.

9. Galic V, Herzog TJ, Lewin SN, Neugut Al, Burke WM, Lu YS, Hershman DL, Wright JD: Prognostic significance of adenocarcinoma histology in women with cervical cancer. Gynecol Oncol 2012, 125:287-291.

10. Tornesello ML, Buonaguro L, Buonaguro FM: Mutations of the TP53 gene in adenocarcinoma and squamous cell carcinoma of the cervix: a systematic review. Gynecol Oncol 2013, 128:442-448.

11. Tommasino M, Accardi R, Caldeira S, Dong W, Malanchi I, Smet A, Zehbe I: The role of TP53 in Cervical carcinogenesis. Hum Mutat 2003, 21:307-312.

12. Bertelsen BI, Steine SJ, Sandvei R, Molven A, Laerum OD: Molecular analysis of the PI3K-AKT pathway in uterine cervical neoplasia: frequent PIK3CA amplification and AKT phosphorylation. Int J Cancer 2006, 118:1877-1883.

13. Zhang A, Maner S, Betz R, Angstrom T, Stendahl U, Bergman F, Zetterberg A, Wallin KL: Genetic alterations in cervical carcinomas: frequent low-level amplifications of oncogenes are associated with human papillomavirus infection. Int J Cancer 2002, 101:427-433.

14. Imoto I, Tsuda H, Hirasawa A, Miura M, Sakamoto M, Hirohashi S, et al: Expression of CIAP1, a target for 11q22 amplification, correlates with resistance of cervical cancers to radiotherapy. Cancer Res 2002, 62:4860-4866.

15. Alonio LV, Picconi MA, Dalbert D, Mural J, Bartt O, Bazan G, Dominguez M, Teyssié AR: Ha-ras oncogene mutation associated to progression of papillomavirus induced lesions of uterine cervix. J Clin Virol 2003, 27:263-269.

16. Cheung TH, Lo KW, Yim SF, Chan LK, Heung MS, Chan CS, Cheung AY, Chung TK, Wong YF: Epigenetic and genetic alternation of PTEN in cervical neoplasm. Gynecol Oncol 2004, 93:621-627.

17. Wingo SN, Gallardo TD, Akbay EA, Liang MC, Contreras CM, Boren T, Shimamura T, Miller DS, Sharpless NE, Bardeesy N, Kwiatkowski DJ, Schorge JO, Wong KK, Castrillon DH: Somatic LKB1 mutations promote cervical cancer progression. PLoS One 2009, 4:e5137.

18. Ojesina Al, Lichtenstein L, Freeman SS, Pedamallu CS, Imaz-Rosshandler I, Pugh TJ, Cherniack AD, Ambrogio L, Cibulskis K, Bertelsen B, Romero-Cordoba S, Treviño V, Vazquez-Santillan K, Guadarrama AS, Wright AA, Rosenberg MW, Duke F, Kaplan B, Wang R, Nickerson E, Walline HM, Lawrence MS, Stewart C, Carter SL, McKenna A, Rodriguez-Sanchez IP, Espinosa-Castilla M, Woie K, Bjorge L, Wik E: Landscape of genomic alterations in cervical carcinomas. Nature 2014, 506:371-375

19. Nigro JM, Baker SJ, Preisinger AC, Jessup JM, Hostetter R, Cleary K, Signer SH, Davidson N, Baylin S, Devilee P, Glover T, Collins FS, Weslon A, Modali R, Harris CC, Vogelstein B: Mutations in the $\mathrm{p} 53$ gene occur in diverse human tumour types. Nature 1989, 342:705-708.

20. Petitjean A, Achatz MI, Borresen-Dale AL, Hainaut P, Olivier M: TP53 mutations in human cancers: functional selection and impact on cancer prognosis and outcomes. Oncogene 2007, 26:2157-2165.

21. Munro AJ, Lain S, Lane DP: P53 abnormalities and outcomes in colorectal cancer: a systematic review. $\mathrm{Br} J$ Cancer 2005, 92:434-444.

22. Vogelstein B, Lane D, Levine AJ: Surfing the p53 network. Nature 2000, 408:307-310.

23. Vousden $\mathrm{KH}$ : Switching from life to death: the Miz-ing link between Myc and p53. Cancer Cell 2002, 2:351-352.

24. Petitjean A, Mathe E, Kato S, Ishioka C, Tavtigian SV, Hainaut P, Olivier M: Impact of mutant p53 functional properties on mutation patterns and tumor phenotype: lessons from recent developments in the IARC database. Hum Mutat 2007, 28:622-629.

25. Karakas B, Bachman KE, Park BH: Mutation of the PIK3CA oncogene in human cancers. Br J Cancer 2006, 94:455-459.

26. McIntyre JB, Wu JS, Craighead PS, Phan T, Kobel M, Lees-Miller SP, Ghatage P, Magliocco AM, Doll CM: PIK3CA mutational status and overall survival in patients with cervical cancer treated with radical chemoradiotherapy. Gynecol Oncol 2013, 128:409-414.

27. Ma YY, Wei SJ, Lin YC, Lung JC, Chang TC, Whang-Peng J, Liu JM, Yang DM, Yang WK, Shen CY: PIK3CA as an oncogene in cervical cancer. Oncogene 2000, 19:2739-2744.

28. Wright AA, Howitt BE, Myers AP, Dahlberg SE, Palescandolo E, Van HP, Van Hummelen P, MacConaill LE, Shoni M, Wagle N, Jones RT, Quick CM, Laury A, Katz IT, Hahn WC, Matulonis UA, Hirsch MS: Oncogenic mutations in cervical cancer: genomic differences between adenocarcinomas and squamous cell carcinomas of the cervix. Cancer 2013, 119:3776-3783.

29. Carnero A: Novel inhibitors of the PI3K family. Expert Opin Investig Drugs 2009, 18:1265-1277.

30. Janku F, Wheler JJ, Westin SN, Moulder SL, Naing A, Tsimberidou AM, Fu S, Falchook GS, Hong DS, Garrido-Laguna I, Luthra R, Lee JJ, Lu KH, Kurzrock R: $\mathrm{PI3K} / \mathrm{AKT} / \mathrm{mTOR}$ inhibitors in patients with breast and gynecologic malignancies harboring PIK3CA mutations. J Clin Oncol 2012, 30:777-782.

31. Tornesello ML, Losito S, Benincasa G, Fulciniti F, Botti G, Greggi S, Buonaguro L, Buonaguro FM: Human papillomavirus (HPV) genotypes and HPV16 variants and risk of adenocarcinoma and squamous cell carcinoma of the cervix. Gynecol Oncol 2011, 121:32-42.

32. Carozzi FM, Tornesello ML, Burroni E, Loquercio G, Carillo G, Angeloni C, Scalisi A, Macis R, Chini F, Buonaguro FM, Giorgi Rossi P, HPV Prevalence Italian Working Group: Prevalence of Human Papillomavirus Types in High-Grade Cervical Intraepithelial Neoplasia and Cancer in Italy. Cancer Epidemiol Biomarkers Prev 2010, 19:2389-2400.

33. Young RH, Clement PB: Endocervical adenocarcinoma and its variants: their morphology and differential diagnosis. Histopathology 2002, 41:185-207.

34. Fredricks DN, Relman DA: Paraffin removal from tissue sections for digestion and PCR analysis. Biotechniques 1999, 26:198-200.

35. Doorbar J: The papillomavirus life cycle. J Clin Virol 2005, 32(Suppl 1):S7-S15.

36. Annunziata C, Buonaguro L, Buonaguro FM, Tornesello ML: Characterization of the human papillomavirus (HPV) integration sites into genital cancers. Pathol Oncol Res 2012, 18:803-808.

37. Schmutte C, Yang AS, Nguyen TT, Beart RW, Jones PA: Mechanisms for the involvement of DNA methylation in colon carcinogenesis. Cancer Res 1996, 56:2375-2381.

38. Ambs S, Bennett WP, Merriam WG, Ogunfusika MO, Oser SM, Harrington AM, Shields PG, Felley-Bosco E, Hussain SP, Harris CC: Relationship between p53 mutations and inducible nitric oxide synthase expression in human colorectal cancer. J Natl Cancer Inst 1999, 91:86-88.

39. Vaninetti NM, Geldenhuys L, Porter GA, Risch H, Hainaut P, Guernsey DL, Casson AG: Inducible nitric oxide synthase, nitrotyrosine and p53 mutations in the molecular pathogenesis of Barrett's esophagus and esophageal adenocarcinoma. Mol Carcinog 2008, 47:275-285.

40. Jackson AL, Loeb LA: The contribution of endogenous sources of DNA damage to the multiple mutations in cancer. Mutat Res 2001, 477:7-2

41. Matsumoto M, Furihata M, Kurabayashi A, Araki K, Sasaguri S, Ohtsuki Y: Association between inducible nitric oxide synthase expression and p53 status in human esophageal squamous cell carcinoma. Oncology 2003 64:90-96.

42. Harima Y, Sawada S, Nagata K, Sougawa M, Ohnishi T: Chromosome 6p21.2, 18 q21.2 and human papilloma virus (HPV) DNA can predict prognosis of cervical cancer after radiotherapy. Int J Cancer 2001, 96:286-296.

43. Forbes SA, Bhamra G, Bamford S, Dawson E, Kok C, Clements J, Menzies A Teague JW, Futreal PA, Stratton MR: The Catalogue of Somatic Mutations in Cancer (COSMIC). Curr Protoc Hum Genet 2008, 57. 10.11.1-10.11.26 doi: 10.1002/0471142905.hg1011s57.

44. Cui B, Zheng B, Zhang X, Stendahl U, Andersson S, Wallin KL: Mutation of PIK3CA: possible risk factor for cervical carcinogenesis in older women. Int J Oncol 2009, 34:409-416.

45. Spaans VM, Trietsch MD, Crobach S, Stelloo E, Kremer D, Osse EM, Haar NT van Eijk R, Muller S, van Wezel T, Trimbos JB, Bosse T, Smit VT, Fleuren GJ: Designing a high-throughput somatic mutation profiling panel specifically for gynaecological cancers. PLoS One 2014, 9:e93451.

46. Thomas LK, Bermejo JL, Vinokurova S, Jensen K, Bierkens M, Steenbergen R Bergmann M, von Knebel Doeberitz M, Reuschenbach M: Chromosomal gains and losses in human papillomavirus-associated neoplasia of the lower genital tract - a systematic review and meta-analysis. Eur J Cancer 2014, 50:85-98.

47. Heselmeyer K, Schröck E, du Manoir S, Blegen H, Shah K, Steinbeck R, Auer $\mathrm{G}$, Ried T: Gain of chromosome $3 q$ defines the transition from severe 
dysplasia to invasive carcinoma of the uterine cervix. Proc Natl Acad Sci U S A 1996, 93:479-484.

48. Heselmeyer-Haddad K, Sommerfeld K, White NM, Chaudhri N, Morrison LE, Palanisamy N, Wang ZY, Auer G, Steinberg W, Ried T: Genomic amplification of the human telomerase gene (TERC) in pap smears predicts the development of cervical cancer. Am J Pathol 2005, 166:1229-1238.

49. Yang YC, Shyong WY, Chang MS, Chen YJ, Lin CH, Huang ZD, Wang TY, Hsu MT, Chen ML: Frequent gain of copy number on the long arm of chromosome 3 in human cervical adenocarcinoma. Cancer Genet Cytogenet 2001, 131:48-53.

50. Luhn P, Houldsworth J, Cahill L, Schiffman M, Castle PE, Zuna RE, Dunn ST, Gold MA, Walker J, Wentzensen N: Chromosomal gains measured in cytology samples from women with abnormal cervical cancer screening results. Gynecol Oncol 2013, 130:595-600.

51. Seppo A, Jalali GR, Babkowski R, Symiakaki H, Rodolakis A, Tafas T, Tsipouras P, Kilpatrick MW: Gain of 3q26: a genetic marker in low-grade squamous intraepithelial lesions (LSIL) of the uterine cervix. Gynecol Oncol 2009, 114:80-83.

doi:10.1186/s12967-014-0255-5

Cite this article as: Tornesello et al: TP53 and PIK3CA gene mutations in adenocarcinoma, squamous cell carcinoma and high-grade intraepithelial neoplasia of the cervix. Journal of Translational Medicine 2014 12:255.

\section{Submit your next manuscript to BioMed Central and take full advantage of:}

- Convenient online submission

- Thorough peer review

- No space constraints or color figure charges

- Immediate publication on acceptance

- Inclusion in PubMed, CAS, Scopus and Google Scholar

- Research which is freely available for redistribution 